\title{
ANALISIS PERBANDINGAN KINERJA LAYANAN KEUANGAN KORPORASI DI INDONESIA \\ (Studi Kasus Pada PT. Bank Mega Tbk dan PT. Bank Mega Syariah)
}

\author{
Ayif Fathurrahman; Harun Thalib \\ Universitas Muhammadiyah Yogyakarta \\ e-mail: ayief_ospp@yahoo.com
}

\begin{abstract}
In Indonesia, the banking economy in carrying out its functions is based on the principle of prudence. The main function of banking is to collect funds from the public, and at the same time channel public funds and support the implementation of national development in order to increase the level of equitable development, national economic growth and national economic stability, towards improving the better living standards of the people. It is stated in Act Number 10 of 1998 concerning banking, that banks as business entities collect funds from the public in the form of deposits and distribute them to the public in the form of credit and or other forms in order to improve the standard of living of the community. The purpose of this research is to analize the financial performance comparison between Bank Mega (conventional) and Bank Mega Syariah from 2012 to 2018, by using these financial ratio aspects: CAR (capital adequacy ratio), NPL (non performing loan), ROA (return on assets), BOPO (biaya operasional dan pendapatan operasional), LDR (loan to deposit ratio). The data used in this research is the secondary data obtained from banking statistics issued by Otoritas Jasa Keuangan (OJK) from 2012 to 2018, with using Independent Sample T-Test analysis methode in SPSS 16 software. The result shows that there is a significant difference in LDR, NPL,BOPO ratio and no significant difference in CAR and ROA ratio between PT. Bank Mega Tbk, (conventional) and PT. Bank Mega Syariah in financial performance aspect, PT. Bank Mega Tbk is better. However, in liquidity aspect, PT. Bank Mega Syariah is better.
\end{abstract}

Keywords: capital adequacy ratio, non performing loan, loan to deposit ratio, return on assets

\section{Pendahuluan}

Di Indonesia, dalam perekonomian perbankan dalam menjalankan fungsinya berasaskan pada dasar prinsip kehati-hatian. Fungsi utama perbankan ialah sebagai penghimpun dana dari masyarakat, dan sekaligus penyalur dana masyarakat serta menunjang pelaksanaan pembangunan nasional dalam rangka peningkatan tingkat pemerataan pembangunan, pertumbuhan ekonomi negara dan stabilitas ekonomi nasional, kearah peningkatan taraf hidup rakyat banyak yang lebih baik. Disebutkan dalam Undang-Undang Nomor 10 Tahun 1998 tentang Perbankan, bahwa bank sebagai badan usaha yang menghimpun dana dari masyarakat dalam bentuk simpanan dan menyalurkannya kepada masyarakat dalam bentuk kredit dan atau bentuk lainnya dalam rangka meningkatkan taraf hidup masyarakat.

Sejak tahun 1992, Indonesia memperkenalkan dual banking system atau disebut sistem perbankan ganda, yaitu sistem di mana bank umum konvensional dan bank umum syariah 
diizinkan beroperasi secara berdampingan dalam sebuah ekonomi negara. ${ }^{1}$ Sistem perbankan ganda pada saat itu baru dapat benar-benar diterapkan pada tahun 1998, pada saat pemerintah mengeluarkan kebijakan perubahan undang-undang perbangkan UU No. 10/1998. Peraturan undang-undang tersebut memberikan kesempatan yang lebih luas untuk investor mendirikan bank syariah yang baru, sekalipun untuk bank umum konvensional yang akan membuka unit usaha syariah. $^{2}$

Salah satu investor besar di Indonesia adalah Chairul Tanjung yang masuk jajaran orang terkaya di Indoensia dengan CT Corp-nya. CT Corp adalah sebuah perusahaan induk yang berkembang dengan pesat dan aktif dalam berbagai sektor industri yang ada di Indonesia. Grup ini berdiri sejak tahun 1987 dan pada tahun 2008 group ini mengalami pergantian nama dari Para Group berganti menjadi CT Corp. CT Corp terbagi dalam tiga holding bisnis yang masing-masing berkonsentrasi pada media, gaya hidup dan hiburan, layanan keuangan, dan sumber daya alam. ${ }^{3}$ Dalam layanan keuangan, CT Corp menjadi pemegang saham Bank Mega dan Bank Mega Syariah.

PT Bank Mega Tbk menyediakan layanan perbankan yang luas bagi pelanggan korporat dan ritelnya dan saat ini merupakan salah satu bank papan atas di Indonesia. PT Bank Mega Tbk memiliki fokus khusus pada perbankan konsumen, dan merupakan salah satu penerbit kartu kredit terbesar di Indonesia dengan lebih dari 1,2 juta kartu kredit. ${ }^{4}$ PT Bank Mega Syariah adalah salah satu pelopor dalam industri perbankan syariah di Indonesia. Bank menawarkan rekening tabungan, deposito, tabungan haji dan berbagai produk pinjaman komersial dan konsumen. PT Bank Mega Syariah memiliki fokus khusus pada usaha mikro, kecil dan menengah, dan juga telah memperluas penawaran keuangannya ke gadai, produk pensiun, dan pembiayaan koperasi. ${ }^{5}$

Kedua bank tersebut mempunyai kelebihan dalam menjalankan usahanya dengan strategi sinergi dengan seluruh unit usaha yang tergabung dalam Group CT Corp terutama pada unit usaha ritel. PT Bank Mega Tbk (konvensional) melakukan sinergi untuk memberikan benefit kepada nasabah berupa potongan harga yang berlaku sepanjang masa. Hal ini menjadikan PT Bank Mega Tbk memiliki daya saing tersendiri. PT Bank Mega Syariah melakukan sinerginya dengan unit usaha yang tergabung dalam Group CT Corp yang membuat PT Bank Mega Syariah unggul dan berdaya saing, dan efisien, serta memperluas penetrasi pasar tanpa harus membuka cabang kantor bank Mega Syariah. Dalam perkembanganya, PT Bank Mega Syariah melakukan sinergi dengan mengakses sumber daya dari perusahaan-perusahaan yang tergabung dalam Group CT Corp. Sinergi dilakukan terutama pada perusahaan yang berbasis pada bisnis ritel, dengan mengakses pada beberapa aspek seperti pada sumber daya manusia, teknologi, capital, dan aspek costomer base.

Dalam usaha bank dan lembaga keuangan untuk menilai lancar tidaknya sebuah usaha

\footnotetext{
${ }^{1}$ Pada tahun 1992 didirikanlah Bank Muamalat Indonesia sebangai bank syariah pertama di Indonesia.

2 Ascarya, Bank Syariah: Gambaran Umum, Pusat Pendidikan dan Studi Kebanksentralan (Jakarta: Bank Indonesia, 2005), 9.

${ }^{3}$ Dalam perkembanganya, group CT Corp telah mendirikan perusahaan yang cukup kuat di pasar konsumen, seperti Trans7, TransTV, TransFashion, Transmart, Mega Life, Bank Mega, dan Bank Mega Syariah. Dikutip dari http://ctcorpora.com/, diakses pada Februari 2020.

${ }^{4}$ Dengan melalui kartu kredit, CT Corp memungkinkan sinergi tak tertandingi di seluruh portofolio produk ritel, gaya hidup dan hiburan sehingga memberikan benefit yang luar biasa bagi konsumen Indonesia.

${ }^{5}$ Bank Mega Syariah, Synergy To Build The Best (Jakarta: Annual Report, 2018), 15.
} 
perlu dilakukan penilaian usaha. Salah satu cara untuk mengetahui sehat tidaknya sebuah bank atau lembaga keuangan adalah dengan cara menilai kinerja keuangan. Dalam menilai kinerja sebuah perusahaan lembaga keuangan, dapat diukur dengan menggunakan alat analisis laporan keuangan seperti rasio keuangan.

PT Bank Mega Tbk (konvensional) dan PT Bank Mega Syariah diketahui tergabung dalam Group CT Corpora dan dalam struktur group unit bisnis Mega Corpora, karena berada dalam group yang sama, strategi dalam menjalankan dan mengembangkan bisnisnya hampir sama, yaitu dengan melakukan sinergi dengan perusahaan-perusahaan yang tergabung dalam Group CT Corpora, meskipun dengan prinsip dan produk yang berbeda, untuk setiap transaksi yang menggunakan produk PT Bank Mega Tbk (konvensional) mendapatkan diskon di Carrefour, Baskin \& Robbins, Wendy's, Coffe Bean, Transfashion dan Trans Living, METRO, Anta Java, Trans Studio, ${ }^{6}$ begitu juga dengan PT Bank Mega Syariah setiap transaksi yang menggunakan produknya akan mendapatkan benefit dan diskon di Metro, Transmart, Indeks Living Mall, Baskin \& Robins, Wendys, Coffe Bean dan Tea Leaf Kidscity, Transtudio Mini. Dengan kemiripan strategi tersebut maka perlu dilakukan analisis kinerja keuangan dan perbandingan kinerja antar kedua bank. Berdasarkan uraian di atas sekiranya perlu dilakukan penelitian untuk membandingkan kinerja keuangan serta untuk mengetahui seberapa besar pencapaian dan kemajuan antara PT Bank Mega Tbk (konvensional) dan PT Bank Mega Syariah.

\section{Metode Penelitian}

Obyek penelitian yang dipakai dalam penelitian ini adalah PT Bank Mega Tbk (konvensional) dan PT Bank Mega Syariah yang merupakan salah satu bank devisa yang berada di Indonesia dan merupakan sebuah perusahaan yang berada dalam satu grup holding company CT-Corp.

Penelitian ini menggunakan jenis data sekunder dan data primer. Data sekunder merupakan data yang didapatkan dari dokumentasi instansi pemerintahan, lembaga sosial, hasil studi dan publikasi dari organisasi lembaga yang sejenis. Data sekunder yang digunakan dalam penelitian ini adalah data yang diperoleh dari data laporan keuangan PT Bank Mega Tbk (konvensional) dan PT Bank Mega Syariah yang menjadi objek penelitian. Data dikutip secara langsung dari situs resmi Otoritas Jasa Keuangan (OJK) dan situr resmi PT Bank Mega Tbk (konvensional) dan PT Bank Mega Syariah.

Dalam menganalisis data yang diteliti, peneliti menggunakan alat analisis uji beda ratarata atau uji independent sample t-test. Sebelum pengujian hipotesis akan dilakukan uji asumsi dasar berupa uji normalitas terhadap rangkaian data, dengan tujuan untuk mengetahui apakah populasi data berdistribusi normal atau tidak. Metode kolmogorov-smirnov merupakan sebuah metode untuk menguji data berdistribusi normal atau tidak. Dengan kaidah pengujian sebagai berikut:

1. Jika nilai $p$-value dan sig ( 2 tailed) $>0,05$ maka data variabel berdistribusi normal.

2. Jika nilai p-value dan sig (2 tailed) $<0,05$ maka data variabel tidak berdistribusi normal.

Dalam menghitung nilai t hitung dapat menggunakan rumus sebangai berikut:

\footnotetext{
${ }^{6}$ Bank Mega, Trasformasi Business Model Menuju Digital Ecosystem (Jakarta: Annual Report, 2018 ), 18.
} 


$$
t_{\text {hitung }}=\frac{\overline{X_{1}}-\overline{X_{2}}}{\sqrt{\frac{\left(n_{1}-1\right) S_{1}^{2}+\left(n^{2}-1\right) S_{2}^{2}}{n_{1}+n_{2}-2}\left(\frac{1}{n_{1}}+\frac{1}{n_{2}}\right)}}
$$

\section{Bank Konvensional dan Bank Syariah}

Berdasarkan UU No. 10 Tahun 1998, bank konvensional adalah bank yang melakukan kegiatan usaha dan pelayanan jasa perbankan secara konvensional. Menurut Kasmir, dalam menentukan harga dan keuntungan, bank konvensional menggunakan prinsip penetapan bunga sebagai harga, dalam penentuan tingkat bunga bank konvensional mengacu pada BI Rate yang dikeluarkan oleh Bank Indonesia. Sistem bunga pada bank konvensional ditetapkan pada seluruh produk yang tersedia di bank, baik dalam produk giro, tabungan, deposito hingga kredit. ${ }^{7}$

Sedangkan berdasarkan UU No. 21 Tahun 2008 tentang Perbankan Syariah dijelaskan bahwa perbankan syariah adalah segala sesuatu yang menyangkut tentang bank syariah dan unit usaha syariah, mencakup kelembagaan, kegiatan usaha, serta cara dan proses dalam melaksanakan kegiatan usahanya. Bank syariah adalah bank yang menjalankan kegiatan usahanya berdasarkan prinsip syariah. ${ }^{8}$

Sejarah bank syariah di Indonesia ditandai dengan berdirinya Bank Muamalat Indonesia pata awal 1990-an hal ini mengingat masyarakat Indonesia yang mayoritas penduduknya adalah Islam sehingga kebutuhan akan layanan jasa keuangan atau perbankan yang berbasis syariah, terutama pada pelanggaran bank konvensional mengenai riba, dan kegiatan yang bersifat spekulatif yang non produktif yang hampir sama dengan perjudian, pelanggaran prinsip keadilan, ketidakjelasan, dalam transaksinya. Dan dalam bank yang berprinsip syariah setiap pembiayaan dan investasi harus disalurkan pada kegiatan usaha yang halal dan tidak melanggar syariat. Namun dalam sejarahnya perkembangan bank syariah di Indonesia baru dirasakan pengaruhnya sejak era 1990-an pada era reformasi, pada saat pemerintah dan Bank Indonesia mengeluarkan kebijakan guna mendorong perkembangan perbankan syariah dengan dikeluarkannya UU No. 10 Tahun 1998. Selain itu, pendorong berkembangnya bank syariah juga sangat dipengaruhi oleh ketentuan Bank Indonesia yang memberikan izin pendirian bank syariah yang baru maupun bank konvensional untuk mendirikan Unit Usaha Syariah (UUS).

\section{Kinerja Keuangan}

Berdasarkam keputusan Menteri Keuangan Republik Indonesia No. 740/KMK.00/1989 tanggal 28 Juni 1989, kinerja adalah potensi yang dicapai oleh perusahaan selama periode tertentu yang mencerminkan tingkat kesehatan dari perusahaan tersebut. Dalam industri

\footnotetext{
${ }^{7}$ Kasmir, Analisis Laporan Keuangan (Jakarta: Rajawali Pers, 2009), 31.

${ }^{8}$ Dalam sejarahnya, bank syariah muncul pertama kali di kota kecil Mit Gharm, Mesir pada tahun 1963 sebagai pilot project dalam bentuk tabungan pedesaan. Dalam perkembanganya, selanjutnya muncul pada tahun 1965 di Pakistan dalam bentuk koperasi. Selanjutnya pada tahun 1970-an gerakan bank syariah mulai hidup kembali dengan berdirinya Islamic Development Bank pada 20 Oktober 1975 sebagai lembaga keuangan internasional Islam multilateral. Hal ini yang dinilai sebagai pemicu munculnya berbagai bank seperti Faisal Islamic Bank di Sudan dan Mesir (1977), Kuwait Finance House (1977) dan Dubai Islamic Bank (1975).
} 
keuangan penilaian dilakukan untuk menunjukan tingkat atau capaian keberhasilan yang diperoleh sebuah perusahaan dalam menjalankan usahanya, baik buruknya kinerja keuangan sebuah perusaahan akan berdampak pada kepercayaan masyarakat terhadap perusahaan tersebut dalam menjalankan usahanya.

Untuk menilai kinerja sebuah perusahaan lembanga keuangan dapat diukur dengan menggunakan alat analisis laporan keuangan seperti rasio keuangan. ${ }^{9}$

1. Rasio Likuiditas

Rasio likuiditas mengukur kemampuan likuiditas jangka pendek perusahaan dengan melihat aktifa lancar perusahan relatif terhadap utang lancarnya.

2. Aspek Kecukupan Modal

CAR adalah penyediaan modal minimum bagi bank didasarkan pada resiko aktiva dalam arti luas, baik aktiva yang tercantum dalam neraca maupun aktiva yang bersifat administratif sebangai mana yang tercermin pada kewajiban yang bersifat kontijen dan atau komitmen yang disediakan oleh bank bagi pihak ketiga maupun resiko pasar.

3. Sisi Kualitas Aktiva Produktif

Kualitas aktiva produktif (KAP) menunjukan kualitas aset suatu perusahaan yang menghubungkan dengan resiko atas pemberian kredit atau pembianyaan.

4. Rasio Profitabilitas

Rasio profibilitas mengukur kemampuan perusahaan menghasilkan keuntungan (profibilitas) pada tingkat penjualan, aset, dan modal saham yang tertentu.

5. Rasio efisiensi

Rasio BOPO digunakan untuk mengukur kemampuan manajemen perusahaan dalam mengendalikan biaya operasional dalam kegiatan.

\section{Analisis Deskriptif}

Statistik deskriptif dalam penelitian ini dapat dilihat pada tabel 1.1. sebagai berikut:

Tabel 1.1. Hasil Olah Data Statistik Deskriptif

\begin{tabular}{|l|c|c|}
\hline \multicolumn{1}{|c|}{ KETERANGAN } & N & RATA-RATA \\
\hline CAR (konvensional) & 28 & 19.6654 \\
\hline CAR (syariah) & 28 & 18.4043 \\
\hline NPL (konvensional) & 28 & 1.8871 \\
\hline NPL (syariah) & 28 & 2.9868 \\
\hline ROA (konvensional) & 28 & 2.1054 \\
\hline ROA (syariah) & 28 & 1.8343 \\
\hline BOPO (konvensional) & 28 & 82.4350 \\
\hline BOPO (syariah) & 28 & 89.9121 \\
\hline LDR (konvensional) & 28 & 62.7461 \\
\hline LDR (syariah) & 28 & 94.6046 \\
\hline
\end{tabular}

Sumber : data olah SPSS16

\section{Analisis Deskriptif Rasio CAR}

\footnotetext{
${ }^{9}$ Syafri S. Harahap, Analisis Kritis Atas Laporan Keuangan (Jakarta: PT Bumi Aksara, 2013), 41.
} 
Berdasarkan tabel 1.1. di atas, rasio CAR pada PT Bank Mega Tbk (kovensional) sebesar 19.6654\%, sedangkan pada PT Bank Mega Syariah sebesar 18.4043\%. Hal ini menunjukan bahwa kecukupan modal pada PT Bank Mega Tbk (konvensional) dalam menanggung rasiko kerugian lebih baik dari pada PT Bank Mega Syariah.

2. Analisis Deskriptif Rasio NPL/NPF

Berdasarkan tabel 1.1. di atas, rasio NPL pada PT Bank Mega Tbk (konvensional) sebesar $1.8871 \%$ dibandingkan dengan PT Bank Mega Syariah sebesar $2.9868 \%$ menunjukkan bahwa kredit macet pada PT Bank Mega Tbk (konvensional) lebih kecil dari pada PT Bank Mega Syariah, yang menunjukan bahwa kinerja PT bank Mega Tbk (konvensional) lebih baik dibandingkan dengan PT Bank Mega Syariah, karena semakin kecil nilai rasio NPL menunjukan semakin kecil juga resiko kredit macet yang ditanggung oleh suatu bank.

3. Analisis Deskriptif Rasio ROA

Berdasarkan tabel 1.1. di atas, rasio ROA pada PT Bank Mega Tbk (konvensional) menunjukan rata-rata Rasio ROA sebesar 2.1054\%, sedangkan rasio PT Bank Mega Syariah sebesar 1.8343\% menunjukan bahwa kemampuan PT Bank Mega Tbk (konvensional) lebih baik dari pada PT Bank Mega Syariah dalam memperoleh keuntungan, dari segi penggunaan asset, semakin tinggi nilai Rasio ROA maka semakin tinggi pula keuntungan yang dihasilkan suatu bank.

4. Analisis Deskriptif Rasio BOPO

Berdasarkan tabel 1.1. di atas, Rasio BOPO pada PT Bank Mega Tbk (konvensional) menunjukan rata-rata rasio sebesar $82.4350 \%$, sedangkan rasio PT Bank Mega Syariah sebesar $89.9121 \%$ menunjukan bahwa kinerja PT Bank Mega Tbk (konvensinal) lebih baik daripada PT Bank Mega Syariah dalam aspek efisiensi biaya operasional. Di mana semakin kecil rasio BOPO maka semakin efisien biaya operasional suatu bank.

5. Analisis Deskriptif Rasio LDR/FDR

Berdasarkan tabel 1.1. di atas, rasio LDR pada PT Bank Mega Tbk (konvensional) menunjukan rata-rata rasio sebesar $62.7461 \%$, sedangkan rasio PT Bank Mega Syariah sebesar 94.6046\% menunjukan bahwa PT Bank mega Syariah lebih baik dari pada PT Bank mega Tbk (konvensional). Hal ini disebabkan karena semakin tinggi rasio LDR, maka semakin tinggi likuiditasnya, yang menandakan tingkat kemampuan bank dalam memenuhi kewajiban dana pihak ketiga atau dana nasabahnya dapat dipenuhi.

\section{Uji Normalitas}

1. Uji Normalitas PT Bank Mega Tbk (konvensional)

Uji Normalitas PT Bank Mega Tbk (konvensional) dengan data rasio keuangan kuartalan selama periode 2012-2018 yang berjumlah dua puluh delapan data yang terdiri dari rasio keuangan CAR, NPL, ROA, BOPO, dan LDR.

Tabel 1.2. Hasil Uji Normalitas Bank Mega (Konvensional)

\begin{tabular}{|l|c|c|c|c|c|}
\hline & $\mathrm{CAR}$ & $\mathrm{NPL}$ & $\mathrm{ROA}$ & $\mathrm{BOPO}$ & $\mathrm{LDR}$ \\
\hline $\mathrm{N}$ & 28 & 28 & 28 & 28 & 28 \\
\hline Kolmogorov-Smirnov $Z$ & 1.149 & .583 & .613 & .661 & .646 \\
\hline
\end{tabular}




\begin{tabular}{|l|l|l|l|l|l|}
\hline Asymp. Sig. (2-tailed) & .143 & .886 & .847 & .775 & .799 \\
\hline Sumber : data olah SPSS16
\end{tabular}

Berdasarkan tabel 1.2. di atas menunjukkan hasil K-S dari masing-masing rasio pada PT Bank Mega Tbk (konvensional) adalah > 0.05. Nilai CAR sebesar 0.143\%. NPL sebesar $0.886 \%$. ROA sebesar $0.847 \%$. BOPO sebesar $0.775 \%$. LDR sebesar $0.799 \%$. Sehingga dapat disimpulkan bahwa semua variabel rasio yang keuangan pada PT Bank Mega Tbk (konvensional) data berdistribusi normal.

2. Uji Normalitas PT Bank Mega Syariah

Uji Normalitas PT Bank Mega Syariah dengan data rasio keuangan kuartalan selama periode 2012-2018 yang berjumlah dua puluh delapan data yang terdiri dari rasio keuangan CAR, NPF, ROA, BOPO, dan FDR.

Tabel 1.3. Hasil Uji Normalitas Bank Mega Syariah

\begin{tabular}{|l|c|c|c|c|c|}
\hline & $\mathrm{CAR}$ & $\mathrm{NPL}$ & $\mathrm{ROA}$ & $\mathrm{BOPO}$ & $\mathrm{LDR}$ \\
\hline $\mathrm{N}$ & 28 & 28 & 28 & 28 & 28 \\
\hline Kolmogorov-Smirnov $\mathrm{Z}$ & .824 & .614 & .513 & .590 & .604 \\
\hline Asymp. Sig. (2-tailed) & .505 & .845 & .955 & .878 & .859 \\
\hline
\end{tabular}

Sumber : data olah SPSS 16

Berdasarkan tabel 1.3. di atas menunjukkan hasil K-S dari masing-masing rasio pada PT Bank Mega Syariah > 0.05. Nilai CAR sebesar 0.505\%. NPL sebesar 0.845\%. ROA sebesar $0.955 \%$. BOPO sebesar $0.878 \%$. LDR sebesar 0.859\%. Sehingga dapat disimpulkan bahwa semua variabel rasio keuangan pada Bank Mega Syariah data berdistribusi normal.

\section{Uji Independent Sample T-Test}

1. Ratio Capital Adequacy Ratio (CAR)

Uji independent sample t-test untuk rasio CAR dalam penelitian ini menggunakan rasio CAR dari laporan keuangan kedua bank selama periode 2012-2018.

Tabel 1.4. Hasil Uji Independent Sample T-Test Rasio CAR

\begin{tabular}{|c|c|c|}
\hline \multirow{4}{*}{ Rasio CAR } & \multicolumn{2}{|c|}{ Independent Sample T-Test } \\
\cline { 2 - 3 } & $\mathrm{T}$ & Sig. (2-tailed) \\
\cline { 2 - 3 } & 1.128 & .264 \\
\cline { 2 - 3 } & 1.128 & .264 \\
\hline
\end{tabular}

Sumber : data olah SPSS 16

Berdasarkan tabel di atas, hasil uji rasio keuangan CAR pada PT Bank Mega Tbk (konvensional) dan PT Bank Mega Syariah memiliki t statistik CAR adalah 1.128 dengan signifikansi 0.264>0.05, maka $H_{0}$ diterima dan $H_{a}$ ditolak dan dapat disimpulkan bahwa rasio CAR pada PT Bank Mega Tbk (konvensional) dan PT Bank Mega Syariah tidak memiliki perbedaan yang signifikan. 
Berdasarkan perbandingan rata-rata dari tabel 1.1. di atas, rasio CAR pada PT Bank Mega Tbk (kovensional) sebesar 19.6654\%, sedangkan pada PT Bank Mega Syariah sebesar $18.4043 \%$. Hal ini menunjukan bahwa secara keseluruhan kecukupan modal pada PT Bank Mega Tbk (konvensional) dalam menanggung rasiko kerugian lebih baik dari pada PT Bank Mega Syariah.

Rasio CAR digunakan untuk mengukur tingkat kemampuan bank, dalam memenuhi atau menunjang kecukupan modal bank sebagai penunjang dalam menghadapi aktiva yang beresiko seperti penyaluran pembiayaan atau kredit.

Faktor yang menyebabkan kedua bank tersebut untuk rasio CAR tidak memiliki perbedaan yang signifikan adalah karena strategi, sumber daya, dan modal aset yang digunakan dalam menjalankan usahanya hampir sama, mengingat bahwa kedua bank tersebut merupakan bagian dari anak perusahaan dari group CT Corp dan tergabung dalam struktur Mega Corpora yang merupakan sebuah perusahaan induk dari layanan keuangan dan berkomitmen untuk menjadi penyedia layanan keuangan satu atap dengan layanan mulai dari perbankan, asuransi, pasar modal dan pembiayaan.

Hal ini memungkinkan menjadi salah satu faktor yang mempengaruhi kedua bank memiliki struktur modal yang cukup kuat, dengan berada pada grup bisnis yang sama kedua bank tersebut mudah dalam melakukan sinergi dan kerja sama dalam menjalankan usahanya.

Strategi PT Bank Mega Syariah adalah menjalin sinergi dengan perusahaan yang tergabung dalam group CT Corp, di antaranya menjalin kerja sama dengan sister companinya, yakni PT Bank Mega Tbk sebagai bank konvensional. Selain itu di tahun 2018, PT Bank Mega Syariah melakukan ekspansi usaha pada segmen retail funding dan pembiayaan konsumen dan melanjutkan ekspansi pada segmen komersial. Segmen bisnis tersebut sebenarnya telah dilakukan oleh PT Bank Mega Tbk. Berdasarkan hal tersebut, dapat disimpulkan bahwa kedua bank dalam mengembangkan bisnisnya memiliki strategi yang hampir sama. Hal ini menjadi salah satu faktor penyebab untuk aspek permodalan antara kedua bank cenderung tidak memiliki perbedaan yang signifikan.

2. Ratio Non performing Loan (NPL)

Uji independent sample t-test untuk rasio NPL dalam penelitian ini menggunakan rasio NPL dari laporan keuangan kedua bank selama periode 2012-2018.

Tabel 1.5. Hasil Uji Independent Sample T-Test Rasio NPL

\begin{tabular}{|c|c|c|}
\hline \multirow{4}{*}{ Rasio NPL } & \multicolumn{2}{|c|}{ Independent Sample T-Test } \\
\cline { 2 - 3 } & $\mathrm{T}$ & Sig. (2-tailed) \\
\cline { 2 - 3 } & -5.672 & .000 \\
\cline { 2 - 3 } & -5.672 & .000 \\
\hline
\end{tabular}

Sumber : data olah SPSS 16

Berdasarkan tabel di atas, hasil uji rasio keuangan NPL pada PT Bank Mega Tbk (konvensional) dan PT Bank Mega Syariah memiliki t statistik NPF adalah -5.672 dengan signifikansi $0.000<0.05$, maka $H_{0}$ ditolak dan $H_{a}$ diterima. Dapat disimpulkan bahwa rasio NPL pada PT Bank Mega Tbk (konvensional) dan PT Bank Mega Syariah memiliki perbedaan yang signifikan. Dengan demikian, $\mathrm{H}_{2}$ diterima karena hasil penelitian 
menunjukan bahwa rasio NPL antara PT Bank Mega Tbk (konvensional) dan PT Bank Mega Syariah memiliki perbedaan yang signifikan.

Berdasarkan perbandingan rata-rata pada tabel 1.1. di atas, rasio NPL pada PT Bank Mega Tbk (konvensional) sebesar 1.8871\% dibandingkan dengan PT Bank Mega Syariah sebesar 2.9868\% menunjukkan bahwa kredit macet pada PT Bank Mega Tbk (konvensional) lebih kecil dari pada PT Bank Mega Syariah) yang menunjukan bahwa kinerja PT Bank Mega (konvensional) lebih baik dibandingkan dengan PT Bank Mega Syariah, karena semakin kecil nilai rasio NPL menunjukan semakin kecil juga resiko kredit macet yang ditanggung oleh suatu bank.

Rasio NPL (non performing loan) adalah salah satu rasio untuk mengukur resiko usaha bank, yang ditunjukan oleh tingkat resiko kredit bermasalah pada bank tersebut. Semakin tinggi rasio NPL mengambarkan kualitas pembiayaan pada suatu bank buruk.

Keunggulan PT Bank Mega Tbk (konvensional) dalam mengelola kredit bermasalah, dengan melakukan proses penyeleksian pada saat akuisisi calon debitur baru sehingga mendapatkan debitur yang berkualitas, selain itu PT Bank Mega Tbk melakukan account maintanance dan sinyal peringatan awal melalui aktivitas check on the spot secara berkala untuk melihat perkembangan debitur dan dalam penyelesaiannya dengan meningkatkan intensitas eksekusi melalui proses lelang dan atau pengambilan alihan jaminan debitur melalui proses AYDA.

PT Bank Mega Tbk untuk segmen kreditnya didominasi oleh kredit korporasi yang fokus pada kredit sindikasi dan BUMN dengan kondisi keuangan dengan rating baik dan memiliki proyeksi usaha yang mengalami pertumbuhan. Sedangkan untuk PT Bank Mega Syariah untuk sektor pembiayaannya didominasi oleh segmen join finance dan pada tahun 2018 melakukan pengembangan pembiayaan komersial guna menyeimbangi pembiayaan join finance. Artinya, keunggulan PT Bank Mega Tbk Dalam mengelola kredit bermasalah dinilai wajar disebabkan dominasi segmen kredit pada PT Bank Mega Tbk (konvensional) lebih fokus pada kredit korporasi, yakni penyaluran pada perusahaan-perusahaan, termasuk BUMN sehingga resiko yang ditanggung oleh bank lebih kecil dibandingkan penyaluran kredit atau pembiayaan pada segmen join finance, dan pada segmen pembiayaan komersial, atau pembiayaan pada sektor-sektor lainnya.

Salah satu faktor yang mempengaruhi tingginya kredit atau pembiayaan bermasalah pada PT Bank Mega Syariah dibandingkan dengan PT Bank Mega Tbk sebagai bank konvensional disebabkan PT Bank Mega syariah masih dalam upaya pengembangan usaha dan sehingga diperlukan beberapa stategi untuk meminimalkan pembiayaan bermasalahnya. Dan tetap menyalurkan pembiayaan secara efektif sehingga dapat memaksimalkan laba. Meskipun demikian, kedua bank tersebut memiliki tingkat kredit bermasalah dalam kategori sehat, yakni berada di bawah standar maksimum dari peraturan Bank Indonesia yaitu 5 persen.

3. Ratio Return On Asset (ROA)

Uji independent sample t-test untuk rasio NPL dalam penelitian ini menggunakan rasio NPL dari laporan keuangan kedua bank selama periode 2012-2018.

Tabel 1.6. Hasil Uji Independent Sample T-Test Rasio ROA 


\begin{tabular}{|c|c|c|}
\hline \multirow{3}{*}{ Rasio ROA } & \multicolumn{2}{|c|}{ Independent Sample T-Test } \\
\cline { 2 - 3 } & $\mathrm{T}$ & Sig. (2-tailed) \\
\cline { 2 - 3 } & .855 & .397 \\
\cline { 2 - 3 } & .855 & .399 \\
\hline
\end{tabular}

Sumber : data olah SPSS 16

Berdasarkan tabel 1.6. di atas, hasil uji rasio keuangan ROA pada PT Bank Mega Tbk (konvensional) dan PT Bank Mega Syariah memiliki t statistik ROA adalah 0.855 dengan signifikansi $0.399>0.05$, maka $H_{0}$ diterima dan $H_{a}$ ditolak sehingga dapat disimpulkan bahwa rasio ROA pada PT Bank Mega Tbk (konvensional) dan PT Bank Mega Syariah tidak memiliki perbedaan yang signifikan. Dengan demikian, $\mathrm{H}_{3}$ ditolak karena hasil penelitian menunjukan bahwa rasio ROA antara PT Bank Mega Tbk (konvensional) dan PT Bank Mega Syariah tidak memiliki perbedaan yang signifikan.

Berdasarkan perbandingan rata-rata pada tabel 1.1. rasio ROA pada PT Bank Mega Tbk (konvensional) menunjukan rata-rata rasio ROA sebesar $2.1054 \%$, sedangkan rasio PT Bank Mega Syariah sebesar $1.8343 \%$ menunjukan bahwa kemampuan PT Bank Mega Tbk (konvensional) lebih baik dari pada PT Bank Mega Syariah dalam memperoleh keuntungan. Dari segi penggunaan aset, semakin tinggi nilai rasio ROA maka semakin tinggi pula keuntungan yang dihasilkan suatu bank.

Salah satu faktor penyebab kedua bank tersebut tidak memiliki perbedaan yang signifikan untuk rasio ROA karena kedua bank tersebut berada pada satu group holding company Group CT-Corp dan tergabung dalam struktur perusahaan Mega Corp yang merupakan perusahaan induk dari layanan keuangan, dengan komitmen untuk menjadi penyedia layanan keuangan satu atap dengan layanan mulai dari perbankan, asuransi, pasar modal dan pembiayaan. Dikarenakan hal tersebut, kedua bank dalam mengelola usahanya dapat dengan mudah melakukan kerja sama baik kedua bank atau dengan semua perusahaan yang tergabung dalam group CT-Corp. Hal ini ditunjukan juga dari strategi kedua bank dalam mengelola usahanya memiliki kesamaan dan bahkan meskipun kedua bank dalam menjalankan usahanya memiliki prinsip yang berbedah, PT Bank Mega Tbk (konvensional) dan PT Bank Mega syariah melakukan sinergi melalui strategi LSB (layanan syariah bank) di mana PT Bank Mega Tbk sebagai bank konvensional diberikan kesempatan untuk menjual produk produk PT Bank Mega Syariah kecuali produk pembiayaan atau kredit, khususnya pada produk tabungan haji.

Artinya, tidak adanya perbedaan yang signifikan untuk rasio ROA antara PT Bank Mega Tbk (konvensional) dengan PT Bank Mega Syariah disebabkan kedua bank dalam menjalankan usahanya dengan melakukan sinergi sebagai perusahaan yang tergabung dalam grup CT-Corp. Dengan Sinergi tersebut, PT Bank Mega Syariah dapat menjual semua produk yang dimilikinya di semua cabang PT Bank Mega Tbk sebagai Bank Konvensional.

4. Biaya Operasional, Pendapatan Operasional (BOPO)

Uji independent sample t-test untuk rasio biaya operasional dan pendapatan nasional dalam penelitian ini menggunakan rasio BOPO dari laporan keuangan kedua bank selama periode 2012-2018. 
Tabel 1.7. Hasil Uji Independent Sample T-Test Rasio BOPO

\begin{tabular}{|c|c|c|}
\hline \multirow{4}{*}{ Rasio BOPO } & \multicolumn{2}{|c|}{ Independent Sample T-Test } \\
\cline { 2 - 3 } & $\mathrm{T}$ & Sig. (2-tailed) \\
\cline { 2 - 3 } & -3.893 & .000 \\
\cline { 2 - 3 } & -3.893 & .000 \\
\hline
\end{tabular}

Sumber : data olah SPSS 16

Berdasarkan tabel di atas, hasil uji rasio keuangan BOPO pada PT Bank Mega Tbk (konvensional) dan PT Bank Mega Syariah memiliki t statistik BOPO adalah -3.893 dengan signifikansi $0.000<0.05$, maka $H_{0}$ ditolak dan $H_{a}$ diterima sehinga dapat disimpulkan bahwa rasio BOPO pada PT Bank Mega Tbk (konvensional) dan PT Bank Mega Syariah memiliki perbedaan yang signifikan. Dengan demikian, $\mathrm{H}_{4}$ diterima karena hasil penelitian menunjukan bahwa Rasio BOPO antara PT Bank Mega Tbk (konvensional) dan Bank Mega Syariah memiliki perbedaan yang signifikan.

Berdasarkan perbandingan rata-rata pada tabel 1.1. rasio BOPO pada PT Bank Mega Tbk (konvensional) menunjukan rata-rata rasio sebesar $82.4350 \%$, sedangkan rasio PT Bank Mega Syariah sebesar 89.9121\% menunjukan bahwa kinerja PT Bank Mega Tbk (konvensinal) lebih baik daripada PT Bank Mega Syariah dalam aspek efisiensi biaya operasional. Di mana semakin kecil rasio BOPO maka semakin efisien biaya operasional suatu bank.

Untuk rasio BOPO pada penilaian kinerja suatu bank digunakan untuk mengukur tingkat efisiensi bank, dalam menjalangkan usahanya. Yakni biaya operasional dan pendapatan operasional (BOPO) semakin kecil tingkat rasio BOPO bank tersebut, mengambarkan bahwa kemampuan manajemen bank dapat mengendalikan biaya operasonal terhadap pendapatan nasional. Dalam penelitian ini ditemukan bahwa kinerja PT Bank Mega Tbk (konvensional) lebih baik dibandingkan dengan kinerja Bank mega Syariah dalam aspek efisiensi.

Unggulnya PT Bank Mega Tbk (konvensional) dalam mengelola usahanya tentu disebabkan oleh faktor strategi, sumber daya manusia, modal, dan teknologi yang lebih maju dibandingkan dengan PT Bank Mega Syariah. Hal ini dapat disimpulkan mengingat bahwa PT Bank Mega Syariah masih dalam pengembangan usaha yang dilihat dari strategi kebijakan perusahaanya masih terikat kuat dengan PT Bank Mega Tbk (konvensional), di antaranya di tahun 2018 PT Bank Mega Syariah melakukan strategi LSB (layanan syariah bank), yakni sinergi antara PT Bank Mega Tbk (konvensional) dengan PT Bank Mega Syariah di mana semua produk nasabah PT Bank Mega Tbk dapat memakai produk PT Bank Mega Syariah kecuali pada produk kredit.

Hal ini menunjukan bahwa PT Bank Mega Syariah dalam mengelola usahanya, terus melakukan upaya untuk menekan biaya operasionalnya dan memaksimalkan laba, tanpa harus mengeluarkan biaya operasional yang lebih dalam mengembangkan usahanya, dengan cara melakukan sinergi dengan perusahaan yang tergabung dalam Grup CT Corp.

Dengan adanya LSB (layanan syariah Bank) PT Bank Mega Syariah dapat menjual semua produk bank syariah di semua cabang PT Bank Mega Tbk sehingga pengembangan jaringan distribusi oleh PT Bank Mega Syariah dapat dimaksimalkan tanpa harus 
mengeluarkan biaya operasional untuk membuka cabang kantor baru khusus untuk PT Bank Mega Syariah.

5. Ratio Loan Deposite Rasio (LDR)

Uji independent sample t-test untuk rasio LDR dalam penelitian ini menggunakan rasio LDR dari laporan keuangan kedua bank selama periode 2012-2018.

Tabel 1.8. Hasil uji Independent Sample T-Test Rasio LDR

\begin{tabular}{|c|c|c|}
\hline \multirow{4}{*}{ Rasio LDR } & \multicolumn{2}{|c|}{ Independent Sample T-Test } \\
\cline { 2 - 3 } & $\mathrm{T}$ & Sig. (2-tailed) \\
\cline { 2 - 3 } & -24.820 & .000 \\
\cline { 2 - 3 } & -24.820 & .000 \\
\hline
\end{tabular}

Sumber : data olah spss 16

Berdasarkan tabel di atas, hasil uji rasio keuangan LDR pada PT Bank Mega Tbk (konvensional) dan PT Bank Mega Syariah memiliki t statistik LDR adalah -24.820 dengan signifikansi $0.000<0.05$, maka $H_{a}$ ditolak dan $H_{a}$ diterima dapat disimpulkan bahwa rasio LDR pada PT Bank Mega Tbk (konvensional) dan PT Bank Mega Syariah memiliki perbedaan yang signifikan. Dengan demikian, $\mathrm{H}_{5}$ diterima kerena hasil penelitian menunjukan bahwa rasio LDR antara PT Bank Mega Tbk (konvensional) dan PT Bank Mega Syariah memiliki perbedaan yang signifikan.

Berdasarkan perbandingan rata-rata pada tabel 1.1. di atas, rasio LDR pada PT Bank Mega Tbk (konvensional) menunjukan rata-rata rasio sebesar $62.7461 \%$, sedangkan rasio PT Bank Mega Syariah sebesar 94.6046\% menunjukan bahwa PT Bank mega Syariah lebih baik dari pada PT Bank mega Tbk (konvensional). Hal ini ditunjukkan bahwa semakin tinggi rasio LDR, maka semakin tinggi tingkat likuiditasnya, yang menandakan tingkat kemampuan bank dalam memenuhi kewajiban dana pihak ketiga atau dana nasabahnya dapat dipenuhi. Namun jika tingkat likuiditasnya terlalu tinggi juga tidak baik.

Rendahnya rasio LDR PT Bank Mega Tbk (konvensional) diakibatkan oleh penyaluran kredit yang terlalu rendah, sehingga berpengaruh pada profit bank tersebut. Penyaluran kredit yang efektif akan mendatangkan laba untuk bank, namun penyaluran kredit yang terlalu tinggi akan berdampak pada resiko likuiditas jika mengabaikan prinsip kehati-hatian. Di tahun 2018 dalam mengatasi rendahnya likuiditas, Bank Mega Tbk (konvensional) berusaha meningkatkan intermediasi dengan memacu penyaluran kredit.

Berbeda dengan PT Bank Mega Syariah yang berada pada tingkat lebih baik yang berada pada kisaran $94.6046 \%$ yang berarti berada pada standar dari peraturan Bank Indonesia yakni antara 85 sampai dengan $110 \%$. Keunggulan PT Bank Mega Syariah dikarenakan dalam penyaluran pembiayaanya selalu memperhatikan prinsip kehati-hatian hal ini dilakukan untuk menekan jumlah pembiayaan yang berpotensi macet atau bermasalah. Dan menjaga modal yang ada agar tetap efektif disalurkan pada segmen yang dinilai dapat menguntungkan bank terutama pada sektor-sektor riil.

\section{Kesimpulan}

Berdasarkan hasil analisis kinerja keuangan PT Bank Mega Tbk (konvensional) dan PT Bank Mega Syariah periode 2012-2018 bahwa berdasarkan hasil statistik deskriptif 
menunjukan bahwa secara keseluruhan rata-rata rasio CAR, NPL, ROA, BOPO untuk PT Bank Mega Tbk (konvensional) lebih baik dari pada PT Bank Mega Syariah. Dan rata-rata rasio LDR untuk PT Bank Mega Syariah lebih baik dibandingkan dengan PT Bank Mega Tbk (konvensional) yang berada di bawah standar dari peraturan Bank Indonesia.

\section{Daftar Rujukan}

Ascarya. Bank Syariah: Gambaran Umum, Pusat Pendidikan dan Studi Kebanksentralan. Jakarta: Bank Indonesia, 2005.

Bank Mega Syariah. Synergy To Build The Best. Jakarta: Annual Report, 2018.

Bank Mega. Trasformasi Business Model Menuju Digital Ecosystem. Jakarta: Annual Report, 2018.

Harahap, Syafri S. Analisis Kritis Atas Laporan Keuangan. Jakarta: PT Bumi Aksara. 2013.

Home, James C. Van dan John M Wachhowicz, Jr. Prinsip-Prinsip Manajemen Keuangan, Edisi 13. Jakarta: Salemba Empat, 2012.

Jumingan. Analisis Laporan Keuangan, cet. I . Jakarta: PT Bumi Aksara, 2006.

Kasmir. Analisis Laporan Keuangan. Jakarta: Rajawali Pers, 2009.

Mamahit, R.M.F., Mangantar, M., dan Rate, P.V. "Analisis Perbandingan Kinerja Keuangan Bank Milik Pemerintah Dengan Bank Milik Swasta Nasional di Indonesia (Periode 2009-2014)", Jurnal Emba, Volume 4, Nomor 1 (2016).

Munadi, M.M., Saerang, I.S., dan Mandagie, Y. "Analisis Perbandingan Kinerja pada Bank Rakyat Indonesia (persero) Tbk dan Bank Mandiri (persero) Tbk Periode 2012-2015”, Jurnal Emba, Volume 5, Nomor 2 (2017).

Supranto. Statistik Teori dan Aplikasi, Edisi 6. Jakarta: Erlangga, 2009.

http://ctcorpora.com/ diakses pada bulan Februari 2019.

https://www.bi.go.id/id/Default.aspx diakses pada bulan Desember 2019.

https://www.ojk.go.id/ diakses pada bulan Desember 2019.

https://www.bankmega.com/ diakses pada April 2019.

http://www.megasyariah.co.id/ diakses pada April 2019. 